\title{
The Application of Planned Behavior Theory to Predict the Consumption of Processed Body-Shaping Milk
}

\author{
F. S. Yulianti* , S. P. Syahlani*, \& F. T. Haryadi \\ Livestock Agribusiness Laboratory, Social and Economic Department \\ Faculty of Animal Science, Gadjah Mada University \\ Jln. Fauna no 3, Bulaksumur, Yogyakarta, Indonesia \\ (Received 12-05-2011; accepted 05-03-2012)
}

\begin{abstract}
ABSTRAK
Penelitian ini bertujuan untuk mengidentifikasi pengaruh sikap, norma subyektif dan kontrol keperilakuan yang dirasakan pada niat beli, dan mengkaji pengaruh niat beli dan kontrol keperilakuan yang dirasakan pada perilaku beli produk susu olahan yang dilengkapi dengan suplemen pembentukan tubuh. Penelitian dilakukan di wilayah Kabupaten Sleman. Penelitian dilakukan dengan desain survai, dan sampel ditentukan dengan menggunakan judgmental sampling method dengan kriteria responden adalah perempuan dengan usia 18-25 tahun dan termasuk dalam kategori bobot badan normal dan overweight. Responden yang digunakan dalam penelitian ini adalah 100 mahasiswi. Kuesioner digunakan sebagai instrumen untuk pengukuran variabel penelitian dan dilakukan pengujian validitas dan reliabilitas atas kuesioner tersebut. Analisis data dilakukan dengan regresi linier sederhana dan berganda. Hasil penelitian menunjukkan bahwa pada kelompok responden dengan bobot badan normal hanya sikap dan kontrol keperilakuan yang dirasakan berpengaruh pada niat beli $\left(P_{\leq} 0,05\right)$, sedangkan pada kelompok responden dengan bobot badan overweight teridentifikasi bahwa sikap, norma subyektif, dan kontrol keperilakuan yang dirasakan berpengaruh signifikan pada niat beli $\left(P_{\leq} \mathbf{0}, 001\right)$. Hasil juga menunjukkan bahwa sikap dan kontrol keperilakuan yang dirasakan berpengaruh pada perilaku beli pada kedua kelompok bobot badan. Hasil penelitian mengarahkan pada pemahaman bahwa kemampuan teori pembelian terencana dalam memprediksi perilaku pembelian meningkat dengan meningkatnya relevansi produk bagi responden.
\end{abstract}

Kata kunci: sikap, norma subyektif, kontrol keperilakuan yang dirasakan, niat beli, perilaku beli

\section{ABSTRACT}

The research aims were to identify the influence of attitude, subjective norms and perceived behavioral control on intention to buy, and effect of intention to buy and perceive behavioral control over buying behavior on processed body-shapping milk which added by supplement for body shaping. Research was conducted in Sleman Regency and design used was survey. Sampling was taken by using judgmental sampling method with criteria that were female, aged 18-25 yr old and was categorized as normal to overweight appearance. Respondents used were 100 undergraduate female students. Questionnaire was used as an instrument in order for data collecting to measure research variable that had been tested on validity and reliability. Analyses used were single and multiple linier regression. The results showed that only attitude and perceived behavioral control influenced $\left(P_{\leq} 0.05\right)$ intention to buy in normal-weight group, while in over-weight group attitude, subjective norm and perceived behavioral control affected $(P \leq 0.001)$ attitude. Then, attitude and perceived behavioral control influenced buying behavior significantly both in normal and overweight. Therefore, it can be concluded that prediction capability of planned behavior theory are better when product relevancy to respondents was closed.

Key words: attitude, subjective norms, perceived behavioral control, intention to buy, consumption behavior

*Corresponding author:

E-mail: ssyahlani@yahoo.com; suci.syahlani@ugm.ac.id 


\section{INTRODUCTION}

Female consumers targeted to the product that are related to physical attractiveness, including food product and to dissatisfaction tendency towards physical appearance. Dissatisfaction is a one of potential triggering factors of product purchase to overcome a problem. Beauty concepts are associated with a slim body, so that various efforts could be carried out to achieve consumers's goal that is consuming foods that support the need to be looked attractive.

Specifically, young women are the most potential group of products that concerned with physical appearance as they have more sensitivity to environment stimulants (Keelan et al., 1992) that is included behavior that concerning to keep slim body shape. The turbulence of psychological emotion experienced by young women leads them to concern on physical appearance and feel dissatisfy with their body shape growth. The environment and media role also affects young women in promoting themselves to care about physical appearance and body image (Cattarin et al., 2000). The concept of slim woman in various media tends to affects self-image concept in young women so that it causes a bigger influence to adapt with the concept. Young women are influenced by the advertising in an easier way and easily interested in a product that can solve their problem for their appearance.

Livestock products processing industry creates the most of the chance by using technology that makes dairy product is not only beneficial for health but also beneficial for beauty values in this case is body shaping. These products provide consumers a modern way to follow a healthy lifestyle, which differs from the conventionally healthy diet defined by nutrition experts (Siro et al., 2008). The product possibly has different value in women with normal weight and overweight. Hoyt \& Kogan (2001) explained that women in these groups tend to wish that they have slimmer body than those in the underweight group. Dissatisfaction in the overweight group is higher and they have interest in buying body-shaping products compared to women with normal weight as an effort to lose weight (Stake \& Lauer, 1987).

Female consumers' attitude towards a beauty product is vary; it depends on the age, product category, need, social economy condition, taste and sense towards product. Consumers' attitude can be an accurate control towards product buying behavior (Trafimow et al., 2002). One of the accurate theories to explain attitude is theory of planned behavior that enables studies that attitude, subjective norm and behavioral control forms an intention to behave through a detail and reasoned decision making process (De Pelsmacker \& Janssens, 2007) including a behavior in consuming food such as modified food, snacks, beef to healthy food (Tuu et al., 2008). The better the attitude and subjective norm towards product buying behavior and the bigger the behavioral control, the stronger the individual intension in buying product (Trafimow et al., 2002). The previous research on processed milk product has been conducted using theory of planned behavior (Carolina et al., 2008; Kim et al.,
2003). Those researches did not show consistent result. Research result of Carolina et al. (2008) showed inconsistency in attitude and behavioral control which is not influence purchasing intention significantly. The inconsistency occurred possibly due to the absence of research identification on product buying behavior complexity. The purchase of infant formula possibly involved a complex buying decision but in the research of Carolina et al. (2008) did not identify respondents involvement towards product, thus probably there was discrepancy in sampling selection in the research. Theory testing on UHT milk was probably inappropriate since buying behavior in the product category is a simple behavior that does not need complex consideration. Wibowo \& Haryadi (2006) explained that motivation related to someone's relevancy with the involvement in an object has a role in forming someone's attitude.

Based on the explanation, it is important to conduct empiric studies to examine the effect of attitude, subjective norm and behavioral control perceived in buying behavior that needs consideration and will be tested in respondents with different involvement towards different products in this case is women with different weight categories namely normal and overweight. The decision of this research setting is in similar product category namely processed milk product spesifically on processes body-shapping milk, it is expected to give a better result testing of theory of planned behavior.

\section{METHODS}

Evaluation is started by determining the individual's attitude towards product. Attitude towards behavior is measured as individual believe that buying processed milk for body shaping will gain certain benefits and evaluation towards the benefits is called as positive or negative for herself. Subjective norm is a respond of individual believe towards reference group and her motivation to comply. Behavioral control perceived is a variable to show how easy or difficult to do the intended action and considered as the reflection of the past experience besides the anticipated obstacles. The better the attitude and subjective norm towards a product buying behavior and the bigger behavioral control, the stronger consumers intention in purchasing a product (Trafimow et al., 2002), in this research is processed milk product for body shaping. Consumers' behavior is determined by desire or the intention to involve in the behavior and behavioral control perceived. When the perceived behavioral control and actual behavior are adjacent or similar, then behavioral control perceived is predicted to create determinative effect directly to the behavior, as resources, skill and cooperation are needed to create behavior. Correlation model between variables in this research can be seen on Figure 1.

Based on the explanation, the hypothesis are as follows:

$\mathrm{H}_{1}$ : The intention to buy processed body-shapping milk is influenced by attitude towards behavior, subjective norm and perceived behavioral control.

$\mathrm{H}_{2}$ : Buying behavior of processed body-shapping milk is influenced by the intention of purchasing pro- 


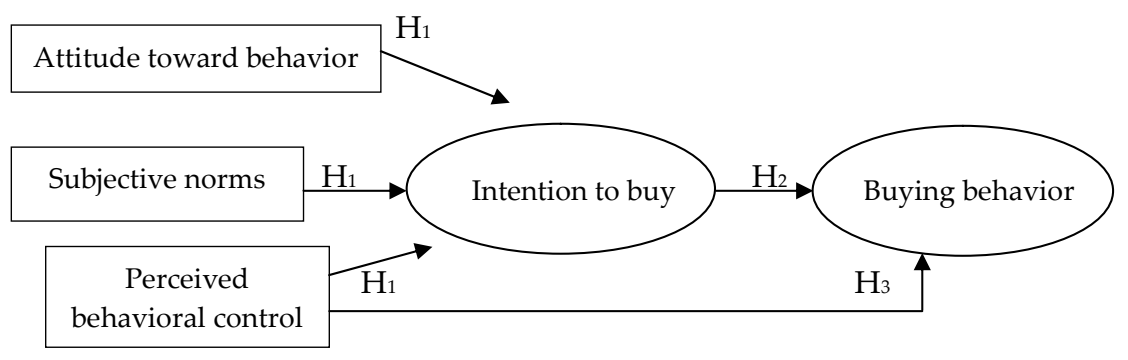

Figure 1. Research model of the application of planned behaviour theory

cessed body-shaping milk.

$\mathrm{H}_{3}$ : Buying behavior of processed body-shapping milk is influenced by perceived behavioral control.

Research survey was conducted in Sleman Regency with 100 respondents. Sample was determined by judgmental sampling method in which respondent criteria are woman, at the age of 18-25 yr old, with normal weight and overweight. Young women were selected based on consideration they are self-objectifying individuals that view themselves as objects which has the tendency to define the self in terms of how the body appears to others, rather than what the body can do or how the body feels (Aubrey, 2006). Product used in this research was body shapping milk product.

The decision of respondents' body shape was measured by Body Mass Index (BMI) formula. BMI was used to measure the accuracy of respondents' weight both with normal weight and the overweight ones. BMI formula is BMI= weight $(\mathrm{kg}) /[\text { height }(\mathrm{m})]^{2}$. For Asians with $\mathrm{BMI} \geq 23$ means that there is overweight problem, $\mathrm{BMI}=18$ up to 22 shows that body weight is in the normal level and BMI $<18$ shows that weight is included under the normal weight level (underweight).

Data were collected through questionnaire in which the validity and reliability to measure research variables those are attitude, subjective norm, perceived behavioral control, purchasing intention and buying behavior and questions related with respondents characteristic have been tested. Likert scale is used to measure those variables by selecting one of the five options namely 5 "strongly agree", 4 "agree", 3 "neutral", 2 "disagree" and 1 "strongly disagree". Validity and reliability test was performed with measurement experiment in 30 respondents. Validity test performed was face validity by noticing that questions in questionnaire have fulfilled variable operational definition that will be measured.

Table 1. Reliability test of research variables

\begin{tabular}{lcc}
\hline \multicolumn{1}{c}{ Variabel } & $\begin{array}{c}\text { No of } \\
\text { items }\end{array}$ & $\begin{array}{c}\text { Cronbach alpha } \\
\text { coefficient }\end{array}$ \\
\hline Attitude towards behavior & 9 & 0.92 \\
Subjective norms & 3 & 0.87 \\
Perceived behavioral control & 4 & 0.92 \\
Intention to buy & 2 & 0.85 \\
\hline
\end{tabular}

Source: Analysis of primary data (2008).
Reliability test was performed with Cronbach Alpha to measure internal consistency of the questions. Table 1 shows that Cronbach Alpha value in the questionnaire experiment is 0.6 thus it can be accepted even it approaches 0.9 .

Data were analyzed by using single and multiple linier regression for hypothesis testing. Mathematical equation for testing $\mathrm{H}_{1}, \mathrm{H}_{2}$ and $\mathrm{H}_{3}$ as below:

$$
\begin{aligned}
& \mathrm{I}=\mathrm{a}+\mathrm{bA}+\mathrm{cSN}+\mathrm{dPBC} \\
& \mathrm{B}=\mathrm{a}+\mathrm{bI} \\
& \mathrm{A}=\mathrm{a}+\mathrm{bPBC}
\end{aligned}
$$

I = intention to buy

B = buying behavior

A = attitude towards behavior

$\mathrm{SN}=$ subjective norms

$\mathrm{PBC}=$ perceived behavioral control

\section{RESULTS AND DISCUSSION}

\section{Influence Factors of Intention to Buy}

There was no statistically significant relation beetwen subjective norm in affecting intention-to-buy in normal-weight respondent group, while attitude and perceived behavioral control significant influenced to intention-to-buy (Table 2). Different result could be found in overweight women that attitude toward behavior, subjective norm as well as perceived behavioral control influenced significantly toward purchasing intention. Attitude toward behavior consistently $(\mathrm{P} \leq 0.05)$ influenced to intention-to-buy in both group. The need to overcome problem that faced by overweight and normal-weight women to be appeared slim increased their relevance or involvement to processed body-shapping milk product. Some empirical research conducted by Rah et al. (2004) on processed soy products; O'Connor \& White (2010) on functional food and vitamin supplement and Arvola et al. (2008) on organic food which were relatively high involvement product, showed similar result that attitude influenced intention-to-buy. Differrent research conducted on low involvement food product category, namely UHT milk, showed that attitude did not influenced towards the intention to buy. UHT milk purchase is a simple thus it does not need a complex and detail consideration and tends to be influenced by a habit, the tendency of repeated behavior beyond the 
Tabel 2. Regression analysis of effect attitude toward behavior, subjective norms, and perceived behavioral control to intention to buy of body shapping milk

\begin{tabular}{lcc}
\hline \multicolumn{1}{c}{ Model } & $\begin{array}{c}\text { Regression } \\
\text { coefficient }\end{array}$ & Signification \\
\hline Normal weight $^{\text {a) }}$ & & \\
Attitude towards behavior & 0.01 & $0.03^{*}$ \\
Subjective norms & -0.00 & 0.86 \\
Perceived behavioral control & 0.02 & $0.03^{*}$ \\
Overweight ${ }^{\text {b) }}$ & & \\
Attitude towards behavior & 0.01 & $0.00^{*}$ \\
Subjective norms & 0.02 & $0.01^{*}$ \\
Perceived behavioral control & 0.02 & $0.00^{*}$ \\
\hline
\end{tabular}

Source: Analysis of primary data (2008).

Note: *significant at P 0.05 ; a) $\mathrm{N}=50$, adjusted $\mathrm{R} 2=0.34$; b) $\mathrm{N}=50$, adjusted $R 2=0.60$.

individual's awareness towards product (Mahon et al., 2006; Tuu et al., 2008).

The influence of subjective norm on intention-tobuy was supported in overweight respondents but it was not in respondents with normal weight. It can be explained that there was no social pressure perceived by respondents with normal weight to consume processed body-shapping milk, where as the overweight respondents perceived that there was a social pressure that came from family, friends to consume body-shaping milk. Study conducted by Kim et al. (2003) showed that social pressure became meaningless on individuals who were able to show self-management experience, whereas social pressure was bigger on individuals who had awareness and motivation to do consumption action (Patch et al., 2005). Overweight women consider more on reference group suggestion to consume product relevant to their problem as the effort to adapt to their environment. Belief and motivation scale caused by subjective norm indicator showed that $68 \%$ and $76 \%$ overweight respondent take into account suggestion from others while only $28 \%$ and $14 \%$ in normal weight respondents.

Behavioral control variable on respondents with normal weight and overweight simultaneously influenced $(\mathrm{P} \leq 0.05)$ on intention-to-buy. Control behavioral variable was found to give a greater contribution compared to the other predictor variables on the intention. Opportunities, resources, and self matters should exist. This study result was consistent with the research of Rah et al. (2004) that behavioral control variable influences purchasing intention. For consumers, product information, purchasing place, and price will increase consumers' intention.

The explanation ability of the three variables is better on overweight respondents, $60 \%$ of purchasing intention on processed milk for body-shaping was influenced by attitude variable, subjective norm and behavioral control, meanwhile in respondents with normal weight the same variable's ability in predicting purchasing intention was only $34 \%$. This result showed that this
Tabel 3. Effect of perceived behavioral control and intention to buy to buying behavior of processed body-shapping milk

\begin{tabular}{lccc}
\hline Model & $\begin{array}{c}\text { Regression } \\
\text { coefficient }\end{array}$ & $\begin{array}{c}\text { Adjusted } \\
\text { R square }\end{array}$ & $\begin{array}{c}\text { Signifi- } \\
\text { cation }\end{array}$ \\
\hline Normal weight & & & \\
$\quad$ Attitude $\rightarrow$ Behavior & 0.45 & 0.55 & $0.00^{*}$ \\
$\quad \begin{array}{l}\text { Perceived behavioral } \\
\text { control } \rightarrow \text { Behavior }\end{array}$ & 0.01 & 0.24 & $0.00^{*}$ \\
$\begin{array}{l}\text { Overweight } \\
\text { Attitude } \rightarrow \text { Behavior }\end{array}$ & 0.49 & 0.47 & $0.00^{*}$ \\
$\quad \begin{array}{l}\text { Perceived behavioral } \\
\text { control } \rightarrow \text { Behavior }\end{array}$ & 0.01 & 0.10 & $0.04^{*}$ \\
\hline
\end{tabular}

Source: Analysis of primary data (2008).

Note: *significant at P 0.05 ; a) $\mathrm{N}=50$, adjusted $\mathrm{R} 2=0.34$; b) $\mathrm{N}=50$, adjusted $\mathrm{R} 2=0.60$.

model had a better prediction on respondents with better relevance towards product.

\section{Influence Factors of Buying Behavior}

Table 3 shows the significant influence of intention and behavioral control towards buying behavior. Buying behavior on processed milk for body-shaping in normal weight as well as the overweight respondents were influenced $(\mathrm{P}<0.05)$ by purchasing intention and behavioral control. This research identified that the influence of intention was stronger than behavioral control. Decision making process shows that if consumers perceive problems or need due to the unachieved desire, there is a desire to make a decision to overcome the problems. The low influence of behavioral control variable is possibly caused by the difficulty to find product availability in the market as well as the conformity of product attribute for other family members (Bogers et al., 2004).

The ability of intention variable in explaining buying behavior was $55 \%$ in normal weight group, meanwhile behavioral control variable was only $24 \%$. In the overweight group, purchasing intention also gave a better ability in explaining buying behavior than behavioral control as much as $47 \%$ compared to $10 \%$.

\section{CONCLUSION}

Attitude towards behavior and perceived behavioral control significantly influenced intention to buy in normal weight group, while subjective norm did not capable to influence intention to buy. For the overweight group all predictor variables which were attitude towards behavior, subjective norms, and perceived behavioral control influenced the intention to buy. Buying behavior both for normal and overweight group is influenced by intention to buy and perceived behavioral control. This research also give knowledge of better prediction accuracy of theory planned behavior is gained if testing on consumer with stronger relevance towards 
to the product. Implication for future research is important to include other variables in the theory of planned behavior that is predicted to disrupt decision making behavior in consumers. For instance, habit is strongly believes as predictor on a relatively simple purchasing.

\section{REFERENCES}

Arvola, A., M. Vassallo, M. Dea, P. Lampila, A. Saba, L. Lahteenmaki, \& R. Shepherd. 2008. Predicting intentions to purchase organic food: the role of affective and moral attitudesin the theory of planned behaviour. Appetite 50: 443-454. http://dx.doi.org/10.1016/j.appet.2007.09.010

Aubrey, J. S. 2006. Exposure to sexually objectifying media and body self-perceptions among college women: an examination of the selective exposure hypothesis and the role of moderating variables. Journal of Sex Roles 55:159-172. http://dx.doi.org/10.1007/s11199-006-9070-7

Bogers, R. P., J. Brug, P. Van Assema, \& P. C. Dagnelie. 2004. Explaining fruit and vegetble consumption: the theory of planned behavior and misconception of personal intake levels. Appetite 42: 156-166. http://dx.doi.org/10.1016/ j.appet.2003.08.015

Carolina, T. F., S. P. Syahlani, \& F. T. Haryadi. 2008. Pengaruh sikap dan niat pada perilaku beli: studi empirik teori planned of behavior pada produk susu formula. Buletin Peternakan 32: 69-77.

Cattarin, J. A., J. K. Thompson, C. Thomas, \& R. Williams. 2000. Body image, mood, and televised images of attractiveness: the role of social comparison. Journal of Social and Clinical Psychology 19:220-239. http://dx.doi.org/10.1521/ jscp.2000.19.2.220

De Palsmacker, P. \& W. Janssens. 2007. The effect of norms, attitudes and habits on speeding behavior: scale development and model building and estimation. Accident Analysis and Prevention 39: 6-15. http://dx.doi.org/10.1016/ j.aap.2006.05.011

Hoyt, W. D. \& L. R. Kogan. 2001. Satisfaction with body image and peer relationship for males and females in a college environment. Journal of Sex Roles 45:199-215. http:// dx.doi.org/10.1023/A:1013501827550

Keelan, J. P., K. K. Dion, \& K. L. Dion. 1992. Correlates of appearance anxiety in late adolescence and early adulthood among young women. Journal of Adolescence 15:193-205. http://dx.doi.org/10.1016/0140-1971(92)90047-9
Kim, K., M. Reicks, \& S. Sjoberg. 2003. Applying the theory of planned bahvior to predict dairy product consumption by older adults. Journal of Nutrition Education Behavior 35:294-301. http://dx.doi.org/10.1016/S1499-4046(06)603436

Mahon, D., C. Cowan, \& M. McCarthy. 2006. The role of attitudes, subjective norm, perceived control and habit in the consumption of ready meals and takeaways in Great Britain. Food Quality and Preference 17: 474-481. http://dx.doi. org/10.1016/j.foodqual.2005.06.001

O'Connor, E. L. \& K. M. White. 2010. Willingness to trial functional foods and vitamin supplements: the role of attitudes, subjective norms and dread of risk. Food Quality and Preference 21: 75-81. http://dx.doi.org/10.1016/ j.foodqual.2009.08.004

Patch, C. S., L. C. Tapsell, \& P. G. Williams. 2005. Attitudes and intentions toward purchasing novel foods enriched with Omega-3 fatty acids. Journal Nutrition Education Behavior 37: 235-241. http://dx.doi.org/10.1016/S14994046(06)60277-7

Rah, J. H., C. M. Hasler, J. E. Painter, \& K. M. Chapman-Novakofski. 2004. Applying theory of planned behavior to women's behavioral attitudes on and consumption of soy products. Journal of Nutrition Education and Behavior 36: 238-244. http://dx.doi.org/10.1016/S1499-4046(06)60386-2

Siro, I., E. Kapolna, B. Kapolna, \& A. Lugasi. 2008. Functional food, product development, marketing and consumer acceptance-review. Appetite 51: 456-467. http://dx.doi. org/10.1016/j.appet.2008.05.060

Stake, J. \& M. L. Lauer. 1987. The consequences of being overweight. A controlled study of gender differences. Journal of Sex Roles 17:31-47. http://dx.doi.org/10.1007/BF00287898

Trafimow, D., J. Brown, K. Grace, L. A. Thompson, \& P. Sheeran. 2002. The reative influence of attitudes and subjective norms form childhood to adolescence: between participant and within participant analysis. American Journal of Psychology 115: 395-414. http://dx.doi.org/10.2307/1423424

Tuu, H. H., S. O. Olsen, D. T. Thao, \& N. T. K. Anh. 2008. The role of norms in explaining attitudes, intention and consumption of a common food (fish) in Vietnam. Appetite 51: 546-551. http://dx.doi.org/10.1016/j.appet.2008.04.007

Wibowo, S. A. \& F. T. Haryadi. 2006. Faktor karakteristik peternak yang mempengaruhi sikap terhadap program kredit sapi di kelompok peternakan Andiniharjo Kabupaten Sleman Yogyakarta. Med. Pet. 29: 176-186. 